\title{
Resiliensi di Masa Pandemi: Peran Efikasi Diri dan Persepsi Ancaman Covid-19
}

\author{
Tri Sulastri ${ }^{1}$, Muhammad Jufri ${ }^{1}$ \\ 1Fakultas Psikologi Universitas Negeri Makassar
}

DOI: http://doi.org/10.29080/jpp.v12i1.531

\begin{abstract}
The Covid-19 pandemic requires individuals to be able to adapt with difficulties and significant changes during this pandemic. Resilience as a function of a healthy adaptation is one of the most needed skills to survive this pandemic. This study aims to explore how individual resilience is affected by self-efficacy and the perceived threat of Covid-19. Participants in this study were 72 people with an age range of 15-32 years. Participants were selected using a non-probability sampling approach. Research instruments used in this study include adapted Brief Resilience Scale, self-efficacy scale, and Covid-19 threat perception scale which is distributed to participants online. Data were analyzed using descriptive analysis and multiple regression analysis. The analysis showed that self-efficacy and perceived threat contributed to individual resilience. The higher the individual self-efficacy, the higher the resilience ability, but a high threat perception can reduce the level of individual resilience.
\end{abstract}

Kata kunci : resilience, self-efficacy, perceived threat

\begin{abstract}
Abstrak : Pandemi Covid-19 menuntut individu untuk dapat beradaptasi dengan kesulitan dan perubahan yang terjadi. Resiliensi sebagai salah satu fungsi adaptasi yang sehat merupakan bentuk kemampuan yang paling dibutuhkan untuk bertahan dalam kondisi pandemi ini. Penelitian ini bertujuan untuk mengeksplorasi bagaimana kemampuan resiliensi individu dipengaruhi oleh efikasi diri dan persepsi ancaman Covid-19. Partisipan dalam penelitian ini sebanyak 72 orang dengan rentang usia 15-32 tahun. Partisipan dipilih dengan menggunakan pendekatan non-probability sampling, yaitu dengan teknik convenience sampling. Instrumen penelitian yang digunakan dalam penelitian ini meliputi The Brief Resilience Scale yang telah diadaptasi, skala efikasi diri, dan skala Persepsi ancaman Covid-19 yang disebarkan kepada partisipan secara online. Teknik analisis data yang digunakan adalah analisis deskriptif dan analisis regresi berganda. Hasil analisis menunjukkan bahwa efikasi diri dan persepsi ancaman memiliki kontribusi terhadap kemampuan resiliensi individu. Semakin tinggi efikasi diri individu maka akan semakin tinggi pula kemampuan resiliensinya, namun persepsi ancaman yang tinggi dapat menurunkan tingkat resiliensi individu.
\end{abstract}

Kata kunci : resiliensi, efikasi diri, persepsi ancaman 


\section{Pendahuluan}

Resiliensi secara umum dapat dimaknai sebagai fungsi adaptasi yang sehat ketika individu mengalami kondisi yang sulit atau situasi yang mengancam (Southwick, Bonanno, Masten, Panter-Brick, \& Yehuda, 2014). Dalam situasi sulit dan tidak pasti seperti masa pandemi ini, individu diharapkan mampu beradaptasi dengan cepat dan bertahan hidup. Resiliensi juga didefinisikan sebagai kemampuan individu untuk dapat menjaga kestabilan fungsi psikologis dan fisiknya ketika mengalami kejadian yang sulit atau mengganggu, seperti kematian kerabat terdekat atau situasi mengancam (Bonanno, 2004). Individu dengan tingkat resiliensi yang tinggi, secara umum mampu menjaga kesehatan fisik dan psikisnya, serta mampu bangkit dengan cepat dari situasi stress atau sulit (Ryff \& Singer, 2003). Semakin tinggi resiliensi yang dimiliki seseorang, maka semakin tinggi keyakinannya untuk dapat mengatasi hal-hal yang baru dan sulit di berbagai aspek kehidupan (De Caroli \& Sagone, 2016).

Kemampuan resiliensi antara individu satu dengan lainnya sangat beragam, hal ini dipengaruhi oleh berbagai factor seperti usia, gender, ras/etnis, status sosioekonomi, pekerjaan, dan status hubungan, serta kondisi sulit yang dialami (Ferreira, Cannon, \& Buttell, 2020). Dalam situasi bencana misalnya, resiliensi individu sangat dipengaruhi oleh gangguan pada fisik maupun mentalnya (Cutter et al., 2013). Berbeda halnya dengan konteks pandemi Covid-19, penelitian lain berusaha untuk mengidentifikasi beberapa factor yang mempengaruhi resiliensi, seperti usia dan tingkat pendidikan, serta persepsi stress. Individu dengan persepsi stress yang tinggi selama periode pembatasan social (lockdown), menunjukkan tingkat resiliensi yang rendah (Ferreira et al., 2020).

Menurut Bandura (Schwarzer \& Warner, 2013) resiliensi juga sangat dipengaruhi oleh keyakinan individu pada kemampuannya dalam melakukan suatu tugas, menyelesaikan masalah, dan mengatasi stressor dalam kehidupannya, yang dikenal dengan istilah efikasi diri (self-efficacy). Individu yang memiliki tingkat efikasi diri yang tinggi dikarakteristikkan dengan keyakinan akan kemampuan diri, melihat hambatan atau masalah sebagai tantangan, kurang merasakan emosi negatif, merasa termotivasi dan persisten saat mengalami hambatan. Sementara individu dengan efikasi diri yang rendah ditandai dengan perasaan ragu akan kemampuan diri, rentan mengalami depresi, menghindari situasi sulit, melihat tugas dan hambatan sebagai hal yang mengancam, serta tidak mampu merespon stressor yang diterima secara efektif (Schwarzer \& Warner, 2013).

Penelitian terkait hubungan antara efikasi diri dan resiliensi telah dilakukan di berbagai konteks, seperti klinis, pendidikan, social, perkembangan, kesehatan, maupun psikologi kepribadian (Schwarzer \& Warner, 2013). Dalam sebuah meta-analisis terhadap 15 penelitian terkait hubungan efikasi diri dan resiliensi, ditemukan hasil bahwa efikasi diri memiliki korelasi yang positif dengan kemampuan resiliensi individu (Utami, 2017). Meskipun penelitian terkait hubungan antara efikasi diri dan resiliensi telah dilakukan diberbagai konteks, namun, belum banyak penelitian yang mengkaji kedua variabel tersebut dalam konteks pandemi, terutama pada kelompok masyarakat di Indonesia. Penelitian ini diharapkan dapat memperkaya literatur terkait kedua variabel tersebut, dan juga ingin mengeksplor bagaimana persepsi ancaman (perceived threat) Covid-19 mempengaruhi resiliensi individu di masa pandemi.

Persepsi ancaman didefinisikan sebagai penilaian kognitif individu terkait tingkat bahaya dari sebuah objek atau situasi dan seberapa besar kondisi tersebut akan berdampak pada dirinya (Goei, 2014). Tingkat persepsi akan bahaya atau ancaman ini selanjutnya akan memprediksi respon adaptif seseorang untuk melindungi dirinya. Berdasarkan teori motivasi perlindungan (protection motivation theory), intensi atau keinginan individu untuk mengadopsi tindakan pencegahan sangat dipengaruhi oleh tingkat persepsi resiko (Khosravi, 2020). Persepsi masyarakat akan tingkat keparahan dan 
kerentanan terhadap ancaman penyakit akan menentukan persepsi ancaman terkait penyakit tersebut (de Zwart dkk, 2009).

Berdasarkan penelitian yang dilakukan oleh Nanda dkk (2021) pada periode awal pandemi (Februari 2020) untuk melihat pengetahuan, tindakan pencegahan, dan persepsi bahaya Covid-19 di Indonesia pada 382 partisipan, ditemukan bahwa sebagian besar partisipan telah memiliki pengetahuan yang baik terkait Covid-19. Namun, persepsi akan bahaya Covid-19 masih sangat rendah dan individu tidak menganggap dirinya berpeluang untuk terjangkit virus ini. Padahal persepsi ancaman akan Covid-19 ditemukan memiliki korelasi yang positif dengan tindakan pencegahan, artinya, ketika individu merasa bahwa Covid-19 ini beresiko dan berbahaya, maka individu akan melakukan tindakan pencegahan yang tepat (Nanda dkk, 2021). Dengan tindakan pencegahan yang tepat, individu akan lebih mampu untuk bertahan di tengah pandemi ini.

Penelitian ini bertujuan untuk memahami resiliensi individu dalam kondisi pandemi sebagai salah satu factor utama untuk dapat beradaptasi dengan situasi saat ini. Pemahaman akan kondisi resiliensi yang dimiliki oleh masyarakat dan faktor yang mempengaruhinya penting untuk dilakukan agar dapat menggambarkan tingkat resiliensi individu dan dapat memberikan masukan terkait intervensi, baik intevensi individu maupun komunitas untuk meminimalisir dampak dari pandemi terhadap kesehatan mental masyarakat (Barzilay dkk, 2020). Hasil dari penelitian ini diharapkan dapat dijadikan sebagai dasar dalam pengembangan intervensi untuk meningkatkan resiliensi masyarakat yang terdampak pandemi. Penelitian ini melihat peranan efikasi diri dan persepsi ancaman covid-19 terhadap tingkat resiliensi masyarakat.

\section{Metode Penelitian}

Penelitian ini merupakan penelitian kuantitatif dengan metode survei. Pendekatan kuantitatif merupakan pengukuran variabel pada individu untuk mendapatkan skor, biasanya dalam bentuk numerik, yang kemudian akan dilakukan analisis statistic untuk diinterpretasi dan disimpulkan (Gravetter \& Forzano, 2018). Variabel yang diteliti dalam penelitian meliputi resiliensi sebagai variabel terikat, serta efikasi diri dan persepsi ancaman terhadap Covid-19 sebagai variabel bebas.

Jumlah partisipan yang tergabung dalam penelitian ini sebanyak 72 orang $(31.9 \%$ laki-laki, 68.1 perempuan). Kriteria inklusi mensyaratkan partisipan berusia 17 tahun ke atas, berstatus sebagai pelajar/mahasiswa, tinggal di wilayah yang memiliki kasus covid19 dan memiliki akses pada link survey. Pengambilan sampel dilakukan dengan pendekatan non-probability sampling, yaitu dengan teknik convenience sampling dimana partisipan dipilih karena aksesibilitas yang mudah dan kedekatannya dengan peneliti (Gravetter \& Forzano, 2018).

Instrumen penelitian yang digunakan dalam penelitian ini meliputi: The Brief Resilience Scale - BRS (Wagnild, 2009) yang telah ditranslasi dan diadaptasi ke dalam Bahasa. Skala efikasi diri dan skala persepsi ancaman (perceived threat) menggunakan sub skala dari Indonesian version of the Champion's Health Belief Model Scale - ICHBMS (Dewi, 2018) yang telah disesuaikan dengan konteks pandemi saat ini. Reliabilitas dari ketiga skala tersebut diindikasikan dengan koefisien Alpha Cronbach sebesar .81 untuk BRS, .68 untuk skala efikasi diri, dan .73 pada skala persepsi ancaman Covid-19.

Data dalam penelitian ini dikumpulkan selama dua minggu pada bulan Mei 2020. Survey dilakukan secara online mengingat kondisi pandemi dan aturan pembatasan sosial. Survey dibuat dengan menggunakan platform google form dan link survey disebarkan melalui berbagai social media, terutama Whats App dan Instagram. Survey ini focus untuk mengeksplor tingkat resiliensi, efikasi diri, persepsi ancaman, serta data demografi partisipan, seperti usia, jenis kelamin, tingkat pendapatan, tingkat pendidikan, status pernikahan, serta agama. Partisipan membutuhkan waktu kurang lebih 10 menit untuk 
menyelesaikan survey tersebut. Data yang terkumpul dianalisis dengan menggunakan bantuan SPSS 23.0 for windows. Teknik analisis yang digunakan adalah uji statistic deskriptif dan analisis regresi berganda untuk melihat bagaimana kontribusi variabel bebas terhadap variabel terikat.

\section{Hasil Penelitian}

Karakteristik partisipan dalam penelitian ini rata-rata berusia 21 tahun $(M=21.3$, $S D=3.53)$, dengan rentang usia 17-39 tahun. Berdasarkan jenis kelamin, jumlah partisipan laki-laki sebanyak 23 orang $(31.9 \%)$ dan perempuan 49 orang (68.1\%). Mayoritas partisipan belum menikah $(91.7 \%, \mathrm{SD}=.278)$. Berdasarkan keyakinan atau agama yang dianut, sebanyak 56 orang $(77.8 \%, \mathrm{SD}=.638)$ beragama Islam, 13 orang Kristen $(18.1 \%)$, dan lainnya beragama Hindu atau Budha (4.2\%).

Analisis deskriptif respon partisipan dalam skala efikasi diri, persepsi ancaman, dan resiliensi dilakukan terhadap total skor dari setiap item pada masing-masing skala. Semakin tinggi nilai total skor yang dihasilkan pada tiap skala, maka mengindikasikan bahwa partisipan memiliki tingkat efikasi diri, persepsi ancaman dan tingkat resiliensi yang tinggi pula. Berdasarkan kategorisasi tingkat resiliensi, efikasi, diri, dan persepsi ancaman Covid-19, sebagian besar partisipan menunjukkan tingkat resiliensi pada level yang sedang (51.4\%) hingga tinggi (48.6\%) dan efikasi diri partisipan cenderung berada pada tingkatan yang tinggi (93.1\%). Selain itu, persepsi ancaman yang dirasakan oleh partisipan akan bahaya Covid-19 berada pada level sedang (72.2\%).

Tabel 1

Tingkat Resiliensi, Efikasi Diri \& Persepsi Ancaman Covid-19

\begin{tabular}{ccccc}
\hline Variabel & Rendah & Sedang & Tinggi & SD \\
\hline Resiliensi & - & $37(51.4 \%)$ & $35(48.6 \%)$ & .503 \\
\hline Efikasi Diri & - & $5(6.9 \%)$ & $67(93.1 \%)$ & .256 \\
\hline Persepsi Ancaman & $11(15.3 \%)$ & $52(72.2 \%)$ & $9(12.5 \%)$ & .530 \\
\hline
\end{tabular}

Analisis regresi berganda dilakukan setelah memastikan bahwa uji prasyarat, seperti uji normalitas, linearitas, multikolinearitas dan uji heteroskedastisitas telah terpenuhi. Hasil analisis regresi berganda pada tabel 2 menunjukkan bahwa terdapat pengaruh yang signifikan dari efikasi diri dan persepsi ancaman Covid-19 terhadap resiliensi individu yang diindikasikan oleh koefisien determinasi $R^{2}=.323(\mathrm{~F}=16.444$, $p=.001$ ). Hal ini menunjukkan bahwa efikasi diri dan persepsi ancaman Covid-19 berkontribusi secara signifikan sebesar $32.3 \%$ terhadap variabilitas pada skor resiliensi di tengah pandemi.

Tabel 2

Hasil Uji Regresi Berganda Prediktor Resiliensi

\begin{tabular}{lccc}
\hline Variabel & Nilai Sig. & Harga Koefisien & Taraf Sig. \\
\hline Persepsi Ancaman & 0.01 & -.414 & 0.05 \\
\hline Efikasi diri & 0.00 & 2.097 & 0.05 \\
\hline
\end{tabular}

Tabel 3

Pengaruh Variabel Prediktor

\begin{tabular}{ccc}
\hline $\mathbf{R}$ & R Square & Adjusted R Square \\
\hline 0.568 & 0.323 & 0.303 \\
\hline
\end{tabular}

Analisis terhadap masing-masing variable menunjukkan bahwa peningkatan skor efikasi diri akan menyebabkan peningkatan pada skor resiliensi. Hal ini diindikasikan dengan skor $B_{1}=2.097$. Sedangkan, hasil analisis pada variabel persepsi ancaman 
menunjukkan tren yang sebaliknya. Peningkatan skor pada persepsi ancaman menyebabkan penurunan skor pada variabel resiliensi, seperti yang diindikasikan pada koefisien $\mathrm{B}_{2}=-.414$.

\section{Pembahasan}

Kategorisasi terhadap skor efikasi diri and resiliensi partisipan menunjukkan bahwa kedua variabel tersebut berada pada skor yang sedang. Hal ini didukung dengan hasil analisis regresi yang menunjukkan bahwa efikasi diri memiliki pengaruh yang positif terhadap resiliensi individu, sehingga semakin tinggi skor efikasi diri seseorang maka semakin tinggi pula resiliensi yang dimilikinya. Temuan ini sejalan dengan hasil meta analisis terhadap 15 penelitian terkait efikasi diri dan resiliensi, yang menunjukkan korelasi positif antara efikasi diri kemampuan resiliensi individu (Utami, 2017). Isaacson (2002) menambahkan bahwa resiliensi merupakan hasil interaksi antara keyakinan dan stressor yang terdapat dilingkungan, sehingga dapat membentuk kemampuan coping pada individu. Hal ini mencakup keyakinan terhadap kemampuan akan diri, hubungan, dan kebaikan yang ada didunia.

Ketika menghadapi situasi sulit dan menantang, individu dengan efikasi diri yang tinggi cenderung mampu untuk mengontrol pikiran mereka, mempertahankan usaha yang dikeluarkan, mengembangkan perasaan berharga akan dirinya, sehingga hal tersebut akan mempengaruhi kemampuan individu untuk bertahan dalam kondisi sulit, seperti kemiskinan, perceraian orangtua, kematian orang yang dicintai, atau situasi sulit lainnya, seperti kondisi pandemi saat ini (Hamill Skoch, 2003). Proses dari efikasi diri ini tergambar dalam mekanisme manifestasi diri dimana individu dengan efikasi diri yang tinggi cenderung ambisius dalam menetapkan tujuan, dan terus berusaha untuk mencapainya, sehingga individu mengembangkan pengalaman menguasai sesuatu (mastery experiences). Dari pengalaman inilah yang kemudian keyakinan individu akan efikasi dirinya meningkat. Di sisi lain, menurut Bandura, individu dengan efikasi rendah cenderung mengalami kegagalan lebih sering karena usaha yang dikeluarkan tidak maksimal dan mudah menyerah ketika menghadapi kesulitan atau tantangan (Vancouver \& Kendall, 2006).

Hasil temuan lainnya dari penelitian ini adalah adanya pengaruh yang negatif dari persepsi ancaman Covid-19 terhadap resiliensi individu dimasa pandemi. Temuan ini tidak sejalan dengan konsep persepsi ancaman bahwa dengan menganggap Covid-19 sebagai hal yang mengancam dan berbahaya, maka individu akan melakukan tindakan preventif untuk meminimalisir kerentanan dan tingkat keparahan dari penularan, serta mencegah penularan dengan mencuci tangan, menjaga jarak, dan menggunakan masker, sehingga akan semakin meningkatkan resiliensi individu di masa pandemi ini.

Persepsi ancaman didefinisikan sebagai penilaian kognitif individu terkait tingkat bahaya dari sebuah objek atau situasi dan persepsi terkait seberapa besar kondisi tersebut akan berdampak pada dirinya (Goei, 2014). Tingkat persepsi akan bahaya atau ancaman ini selanjutnya akan memprediksi respon adaptif seseorang untuk melindungi dirinya. Berdasarkan teori motivasi perlindungan (protection motivation theory), intensi atau keinginan masyarakat untuk mengadopsi tindakan pencegahan sangat dipengaruhi oleh tingkat persepsi resiko (Khosravi, 2020). Persepsi masyarakat akan tingkat keparahan dan kerentanan terhadap ancaman penyakit akan menentukan persepsi ancaman terkait penyakit tersebut (de Zwart et al., 2009).

Hasil analisis deskriptif menunjukkan bahwa mayoritas partisipan memiliki tingkat resiliensi yang cenderung sedang - tinggi, namun persepsi ancaman terhadap bahaya Covid-19 yang berada pada level sedang dan rendah. Meskipun tidak sejalan dengan hasil penelitian sebelumnya, namun hal ini dapat dijelaskan dengan konsep resiliensi yang dapat berubah berubah sepanjang waktu karena resiliensi merupakan hasil dari 
perkembangan dan interaksi individu dengan lingkungan (Kim-Cohen \& Turkewitz, 2012). Misalnya, pengasuhan yang baik dan perlindungan dari orang tua dapat meningkatkan resiliensi dimasa anak-anak, namun mungkin dapat berubah saat masa remaja atau dewasa awal (Southwick et al., 2014).

Selain itu, respon individu terhadap trauma dan kondisi stress tergantung pada interaksi individu dengan orang lain, ketersediaan sumber daya, agama dan budaya tertentu, serta masyarakat dimana individu tinggal (Southwick et al., 2014). Setiap konteks tersebut akan membuat individu memiliki resiliensi yang rendah ataupun tinggi. Oleh karena itu, meskipun persepsi ancaman terhadap Covid-19 cenderung rendah, namun resiliensi yang dimiliki individu tetap tinggi karena banyak faktor lain yang mempengaruhinya. Salah satunya adalah karakteristik demografi partisipan yang mayoritasnya mahasiswa, sehingga pandemi ini lebih banyak berdampak pada interaksi social dengan rekan sebaya dan proses perkuliahan yang dijalani. Oleh karena itu, individu memiliki keyakinan yang tinggi akan kemampuannya melewati masa pandemi ini.

\section{Simpulan dan Saran}

Berdasarkan hasil penelitian yang telah dilakukan, ditemukan bahwa resiliensi individu di masa pandemi dapat dipengaruhi oleh efikasi diri dan persepsi individu akan ancaman Covid-19. Efikasi diri memiliki pengaruh yang positif terhadap resiliensi individu, artinya semakin tinggi efikasi diri yang dimiliki oleh individu, maka akan semakin tinggi pula kemampuan resiliensi individu ketika menghadapi situasi sulit. Di lain sisi, persepsi ancaman yang tinggi terhadap Covid-19 dapat menurunkan kemampuan resiliensi individu dalam menghadapi kondisi pandemi ini. Namun bagaimana bentuk ancaman yang dirasakan secara detail tidak dapat tergali dalam penelitian ini sehingga kajian kualitatif dapat menjadi ide pada penelitian berikutnya. Penelitian selanjutnya diharapkan dapat mengeksplor lebih jauh bagaimana peranan persepsi ancaman ini dengan menempatkannya sebagai variabel yang memoderasi ataupun memediasi hubungan antara efikasi diri dan resiliensi. Selain itu, pada penelitian selanjutnya juga diharapkan dapat melakukan analisis dengan jumlah responden yang lebih banyak, sehingga dapat digeneralisasi pada populasi yang lebih besar.

\section{Daftar Pustaka}

Barzilay, R., Moore, T. M., Greenberg, D. M., DiDomenico, G. E., Brown, L. A., White, L. K., ... Gur, R. E. (2020). Resilience, COVID-19-related stress, anxiety and depression during the pandemic in a large population enriched for healthcare providers. Translational Psychiatry, 10(1), 291. https://doi.org/10.1038/s41398-020-00982-4

Bonanno, G. (2004). Loss, Trauma, and Human Resilience: Have We Underestimated the Human Capacity to Thrive After Extremely Aversive Events? The American Psychologist, 59, 20-28. https://doi.org/10.1037/0003-066X.59.1.20

Cutter, S., Ahearn, J., Amadei, B., Crawford, P., Eide, E., Galloway, G., ... Zoback, M. Lou. (2013). Disaster Resilience: A National Imperative. Environment: Science and Policy for Sustainable Development, 55, 25-29. https://doi.org/10.1080/00139157.2013.768076

De Caroli, M., \& Sagone, E. (2016). Resilience and psychological well-being: differences for affective profiles in Italian middle and late adolescents. International Journal of Developmental and Educational Psychology. Revista INFAD de Psicología., 1, 149. https://doi.org/10.17060/ijodaep.2016.n1.v1.237

Dewi T. K. (2018). Validation of the Indonesian version of Champion's Health Belief Model Scale for breast self-examination. Psychology research and behavior management, 11, 433-438. https://doi.org/10.2147/PRBM.S177124 
de Zwart, O., Veldhuijzen, I. K., Elam, G., Aro, A. R., Abraham, T., Bishop, G. D., ... Brug, J. (2009). Perceived threat, risk perception, and efficacy beliefs related to SARS and other (emerging) infectious diseases: results of an international survey. International Journal of Behavioral Medicine, 16(1), 30-40. https://doi.org/10.1007/s12529-0089008-2

Ferreira, R., Cannon, C., \& Buttell, F. (2020). COVID-19: Immediate Predictors of Individual Resilience. Sustainability, 12, 6495. https://doi.org/10.3390/su12166495

Goei, R. (2014). Perceived Threat. In Encyclopedia of Health Communication (p. Vol. 1, pp. 1050-1051). https://doi.org/10.4135/9781483346427.n411

Gravetter, F. J., \& Forzano, L.-A. B. (2018). Research methods for the behavioral sciences. Cengage Learning.

Gruber, J., Prinstein, M., Abramowitz, J., Albano, A., Aldao, A., Borelli, J., ... Weinstock, L. (2020). Clinical Psychological Science's Call To Action in the Time of COVID-19. https://doi.org/10.31234/osf.io/desg9

Hamill Skoch, S. (2003). Resilience and Self-Efficacy: The importance of efficacy beliefs and coping mechanisms in resilient adolescents. Colgate University Journal of the Sciences, 35.

Isaacson, B. (2002). Characteristics and Enhancement of Resiliency in Young People (University of Wisconsin-Stout). Retrieved https://core.ac.uk/download/pdf/5066112.pdf

Khosravi, M. (2020). Perceived Risk of COVID-19 Pandemic: The Role of Public Worry and Trust. Electronic Journal of General Medicine, 17, em203. https://doi.org/10.29333/ejgm/7856

Kim-Cohen, J., \& Turkewitz, R. (2012). Resilience and measured gene-environment interactions. Development and Psychopathology, 24(4), 1297-1306. https://doi.org/10.1017/S0954579412000715

Nanda, R. O., Lolita, L., Indayati, W., Rusdiyanti, I., Ikhsanudin, A., \& Mareti, S. (2021). Knowledge, precautionary actions, and perceived risk of COVID-19 among Indonesian people. International Journal of Public Health Science (IJPHS), 10(1), 8-15. https://doi.org/10.11591/ijphs.v10i1.20589

Ryff, C. D., \& Singer, B. (2003). Flourishing under fire: Resilience as a prototype of challenged thriving.

Schwarzer, R., \& Warner, L. (2013). Perceived Self-Efficacy and its Relationship to Resilience. In Resilience in Children, Adolescents, and Adults. The Springer Series on Human Exceptionality (pp. 139-150). https://doi.org/10.1007/978-1-4614-49393_10

Sher, L. (2020). The impact of the COVID-19 pandemic on suicide rates. QJM: An International Journal of Medicine, 113(10), 707-712. https://doi.org/10.1093/qjmed/hcaa202

Southwick, S. M., Bonanno, G. A., Masten, A. S., Panter-Brick, C., \& Yehuda, R. (2014). Resilience definitions, theory, and challenges: interdisciplinary perspectives. European Journal of Psychotraumatology, 5, 10.3402/ejpt.v5.25338. https://doi.org/10.3402/ejpt.v5.25338

Utami, C. T. (2017). Self-efficacy dan resiliensi: Sebuah tinjauan meta-analisis. Buletin Psikologi, 25(1), 54-65.

Vancouver, J., \& Kendall, L. (2006). When self-efficacy negatively relates to motivation and performance in a learning context. The Journal of Applied Psychology, 91, 1146-1153. https://doi.org/10.1037/0021-9010.91.5.1146

Wagnild, G. (2009). A review of the Resilience Scale. Journal of Nursing Measurement, 17(2), 105-113. https://doi.org/10.1891/1061-3749.17.2.105

Xiong, J., Lipsitz, O., Nasri, F., Lui, L. M. W., Gill, H., Phan, L., ... McIntyre, R. S. (2020). Impact of COVID-19 pandemic on mental health in the general population: A systematic 
Sulastri T dan Jufri M, Resiliensi di Masa Pandemi: Peran Efikasi Diri dan Persepsi Ancaman Covid-19

review. Journal of Affective Disorders, 277, 55-64.

https://doi.org/10.1016/j.jad.2020.08.001 